\title{
PENDAMPINGAN BELAJAR PENGENALAN BAHASA INGGRIS MENYENANGKAN DARI RUMAH DI MASA PANDEMI COVID 19
}

\author{
Neli Hastuti ${ }^{1)}$, Evi Roviati ${ }^{2)}$ \\ 1) Jurusan Tadris Bahasa Inggris, Fakultas Ilmu Tarbiyah dan Keguruan, IAIN Syekh Nurjati Cirebon, \\ nelihastuti91730@gmail.com \\ 2) Jurusan Tadris Biologi, Fakultas Ilmu Tarbiyah dan Keguruan, IAIN Syekh Nurjati Cirebon, \\ evi1roviati@gmail.com
}

\begin{abstract}
ABSTRAK
Kegiatan pengabdian kepada masyarakat dengan tema "Mengenalkan Dan Membangkitkan Minat Belajar Bahasa Asing (Bahasa Inggris) Pada Anak Di Masa Pandemi Covid19” di lingkungan RT 02 RW 03 Desa Rancawuluh bertujuan untuk membimbing siswa memiliki keterampilan berbahasa Inggris dengan baik dan benar. Masalah utama yang sering dihadapi anak ketika mendengar Bahasa Inggris yaitu stereotip bahwa Bahasa Inggris sangat sulit di pahami dan dipelajari. Yang pada akhirnya siswa kurang minat untuk mempelajarinya dan tidak bisa mengaplikasikan dalam kehidupan sehari-hari. Kegiatan pengabdian yang berupa program bimbingan belajar bahasa berjalan sesuai dengan rencana yang telah direncanakan dengan jumlah siswa 18 anak. Hasil tersebut diperoleh dari metode pendekatan secara langsung dengan melakukan pendataan anak yang mengikuti bimbingan dan kegiatan mengajar. Adapun materi yang disampaikan berupa Introducing Myself, Spelling Alphabet, Daily Activities, The part of The Body, Numbers, etc. Hasil akhir yang diharapkan dari bimbingan bahasa ini adalah para siswa mampu menerapkan penggunaan bahasa di kehidupan seharihari dan mengatasi kesulitan-kesulitan yang anak-anak hadapi pada saat belajar Bahasa Inggris. Anak-anak bisa belajar dengan tenang, enjoy, dan mudah dipahami tentang materi yang disampaikan.
\end{abstract}

Kata Kunci: pendampingan belajar, pengenalan Bahasa Inggris, pandemi COVID-19.

\begin{abstract}
Community service activities with the theme "introducing and arousing interest in foreign languages (English) in children during the Covid19 pandemic" in the RT 02 RW 03 of Desa Rancawuluh aims to guide students to have good and correct English skills. The main problem children often face when hearing English is the stereotype that English is very difficult to understand and learn. Which in the end, students are less interested in learning it and cannot apply it in daily life. Community service activities in the form of a language tutoring program are running according to the planned plan with 18 students. These results were obtained from the direct approach method by collecting data on children who participated in teaching and teaching activities. The material presented was Introducing Myself, Spelling Alphabet, Daily Activities, The part of The Body, Numbers, etc. The final result expected from this language guidance is that students are able to apply the use of language in everyday life and overcome the difficulties they face while learning English. They can learn calmly, enjoy, and are easy to understand about the material presented.
\end{abstract}

Keywords: learning assistance, English learning, pandemic. 


\section{PENDAHULUAN}

Bahasa merupakan alat komunikasi manusia. Tanpa bahasa, manusia takkan pernah bisa berkomunikasi satu sama lain. Kemajuan suatu peradaban manusia didukung karena adanya bahasa. Karena bahasa mempegaruhi semua aspek di kehidupan tak terkecuali Bahasa Inggris. Bahasa Inggris merupakan bahasa universal, bahasa pemersatu dunia. Kemampuan seseorang dalam menggunakan bahasa Inggris sangatlah dibutuhkan seiring dengan kemajuan sebuah negara (Matodang, 2005). Masyarakat dituntut untuk bisa berkomunikasi menggunakan Bahasa Inggris agar terhubung dengan dunia. Kemampuan berbahasa tentu adanya pelatihan yang membutuhkan proses yang tidak instan. Dimulai dari usia dini, anak-anak mulai dikenali dan dilatih Bahasa Inggris. Oleh sebab itu memperkenalkan Bahasa Inggris kepada anakanak usia sekolah dasar sangatlah penting karena merupakan salah satu cara agar anak-anak usia sekolah dasar ini mampu menghadapi untuk mengenal dunia global. Menurut beberapa para ahli, pembelajaran Bahasa Inggris dirasa penting untuk dimulai sedini mungkin. Mengenal dan belajar Bahasa Inggris dapat dilakukan dengan mulai belajar melafalkan huruf, kosa kata dan membaca serta menggunakan kalimat-kalimat dalam Bahasa Inggris dengan baik dan benar.

Pengajaran memiliki arti cara mengajar atau mengajarkan. Dengan demikian pengajaran bisa diartikan perbuatan belajar (oleh siswa) dan mengajar (oleh guru). Pembelajaran merupakan usaha sadar dari guru untuk membuat siswa belajar, yaitu terjadinya perubahan tingkah laku pada diri siswa yang belajar, dimana perubahan itu dengan didapatkannya kemampuan baru yang berlaku dalam wakktu yang relatif lama dan karena adanya usaha (Yamin, 2017). Kurikulum nasional bagi program pendidikan dasar tidak dicantumkan mata pelajaran Bahasa Inggris. Apabila ada mata pelajaran Bahasa Inggris di sekolah dasar, hanya dicantumkan di muatan lokal saja. Muatan lokal dibuat berdasarkan pada kebijaksanaan sekolah dasar masing-masing.

Anak-anak usia sekolah dasar di lingkungan RT/RW 02/03 Desa Rancawuluh, Bulakamba, Brebes pada umumnya tidak mendapatkan mata pelajaran Bahasa Inggris, khususnya di pendidikan sekolah dasar negeri. Karena awal mengenal Bahasa Inggris, ada beberapa kesulitan dalam memahaminya. Anak-anak beranggapan bahwa Bahasa Inggris sulit dipahami maupun diucapkan. Kurangnya motivasi orang tua juga merupakan salah satu faktor anak kurang minat terhadap bahasa. Dorongan dari orang tua untuk mendukung anak mengenal bahasa pun sangat rendah. Kesadaran akan mengenal ilmu pengetahuan lainnya tinggi, namun rendah untuk kesadaran mengenal bahasa asing.

Kesadaran untuk belajar dan mengenal bahasa asing yang rendah ini diperparah dengan munculnya pandemi global akibat penyebaran virus Corona atau yang disebut dengan COVID19 berdampak ke berbagai bidang, termasuk bidang pendidikan, yang memaksa siswa harus 
belajar dari rumah. Belajar di rumah memerlukan pendampingan, baik dari orang tua atau pembimbing belajar lain. Intensitas pendampingan ini dapat mempengaruhi hasil belajar siswa secara signifikan (Ambaryanti, 2013). Keterlibatan orang tua dalam pendampingan belajar Bahasa Inggris anak, terutama selama masa pandemi ketika anak harus belajar di rumah menjadi hal yang sangat krusial (Handayani, 2020; Agustina, 2019). Orang tua harus membantu kesulitan tugas anak, menjelaskan materi yang tidak dimengerti anak dan merespins dengan baik semua pembelajaran daring dari sekolah (Yulianingsih, dkk., 2020; Setyawan, 2020). Namun, kondisi ini tidak dapat terjadi ketika orang tua tidak mampu atau tidak memiliki waktu untuk mendampingi anaknya untuk belajar di rumah, apalagi untuk orang tua yang tidak memiliki kemampuan dalam Bahasa Inggris atau orang tua yang bekerja selama waktu belajar anak. Oleh sebab itu, diperlukan adanya pendampingan dari pihak lain dalam bentuk pengabian kepada masyarakat dalam bentuk kegiatan pengenalan belajar Bahasa Inggris secara menyenangkan bersama tutor mahasiswa tingkat akhir program studi Pendidikan Bahasa Inggris.

Jadi berdasarkan informasi dari lokasi pengabdian, dapat diidentifikasi beberapa permasalahan sebagai berikut:

1. Bagaimana membuat anak tertarik dan termotivasi untuk belajar dan megenal Bahasa Inggris.
2. Kurangnya kesadaran orang tua akan pentingya bahasa dalam kehidupan di era sekarang.

Pelaksanaan kegiatan Pengabdian Kepada Masyarakat ini diselenggarakan menurut situasi dan kondisi masyarakat di lingkungan RT/RW: 02/03, Desa Rancawuluh, Bulakamba, Brebes. Adapun tujuan dari pelaksanaan kegiatan pengabdian tersebut yaitu:

1. Membimbing anak untuk mengenalkan bahasa Inggris di usia kecil.

2. Meningkatkan minat anak untuk belajar bahasa khususnya Bahasa Inggris, sesuai dengan kemampuan anak dengan tidak melupakan esensi pembelajaran anak dikemas dengan mudah dan menyenangkan seperti belajar sambil bermain. Hal ini diwujudkan melalui pendampingan belajar Bahasa Inggris di lingkungan desa.

3. Memberi pengertian kepada orangtua, khususnya para ibu serta masyarakat akan pentingnya belajar bahasa Inggris untuk anak-anak usia sekolah dasar.

4. Mendorong semangat orangtua untuk memotivasi putera dan puterinya yang belajar di tingkat sekolah dasar untuk mulai belajar bahasa

Untuk itulah penulis sangat tertarik untuk mengadakan program bimbingan belajar bahasa terlebih di masa pandemi covid 19 seperti sekarang. Anak-anak dapat memanfaatkan waktu di rumah untuk belajar dan 
mengembangkan diri dengan hal positif. Bimbingan bahasa berupaya mendekatkan ilmu Bahasa Inggris kepada anak dengan dorongan semangat dan motivasi untuk mempelajarinya serta sebagai wujud nyata dari kegatan pengabdian untuk masyarakat, khususnya masyarakat Desa Rancawuluh, Bulakamba, Brebes.

\section{METODOLOGI PENGABDIAN}

\section{Pendekatan}

\section{a. Metode observasi ( pengamatan)}

Metode observasi yaitu pengumpulan data yang dilakukan dengan cara mengamati dan mencatat secara sistematik gejala-gejala yang ada di Desa Rancawuluh. pada metode pengamatan ini, penulis terjun langsung (survei) untuk mengamati secara langsung terhadap fenomena-fenomena sosial yang terjadi. Menurut (Alshenqeeti, 2014: 40) metode pengumpulan data observasi juga mencakup paradigma pengabdian serta pendekatan kualitatif berkontribusi dengan berfokus pada masalah yang ada dilapangan yang memungkinkan proses sosial dan fenomena. Selain itu, observasi juga bertujuan umtuk mendapatkan izin dari pihak terkait, untuk memperoleh gambaran yang tepat tentang kondisi di lokasi mengenai bagaimana respon anak pertama kali ketika mendengar Bahasa Inggris dan sebagainya.

\section{b. Metode Eksperimental}

Metode pendekatan yang diterapkan dalam pengabdian ini adalah eksperimental. Metode eksperimental itu sendiri merupakan metode yang menguji suatu ide, praktik, dan prosedur untuk menentukan hasil atau variabel dependen. Metode eksperimental berisikan cara belajar mengajar yang melibatkan siswa dengan mengalami dan membuktikan sendiri proses dan hasil percobaan (Sudjana, 2004). Penerapan dalam metode ini menggunakan penerapan bimbingan belajar bahasa asing khususnya Bahasa Inggris untuk anak Sekolah Dasar di sekitar lingkungan RT/RW 02/03 Desa Rancawuluh, Bulakamba, Brebes.

\section{Tahapan Proses di Lapangan}

a. Observasi ke masyarakat Desa Rancawuluh RT/RW 02/03 Kecamatan Bulakamba, Kabupaten Brebes.

b. Sosialisasi pentingnya Bahasa Inggris untuk anak kepada orangtua serta pendataan sejumlah anak yang akan mengikuti program bimbingan bahasa.

c. Mengajar secara langsung dengan tatap muka sesuai dengan protokol kesehatan yang dianjurkan.

d. Evaluasi kegiatan sekaligus penyusunan laporan.

\section{PELAKSANAAN KEGIATAN}

Pengabdian kepada masyarakat yang dikemas dalam wujud program bimbingan belajar bahasa asing (Inggris). Kegiatan pengabdian kepada Masyarakat (PKM) di lingkungan warga RT/RW 02/03 Desa Rancawuluh dalam tema " Mengenalkan Dan Membangkitkan Minat Bahasa Asing (Bahasa 
Inggris) Pada Anak Di Masa Pandemi Covid19” dilaksanakan pada Selasa 07 Juli 2020. Program tersebut dirancang untuk mengedukasi ilmu pengetahuan terutama pada bidang bahasa khususnya bahasa Inggris kepada anak anak Sekolah Dasar. Program bimbingan bahasa dimulai dengan introduction dari pengajar yang memperkenalkan diri dan menyampaikan secara singkat maksud dan tujuan kedatangan ke lokasi Bimbingan bahasa yang bertempat di rumah salah satu warga Desa Rancawuluh.

\section{Pembelajaran Bahasa Inggris} Menyenangkan dalam program ini adalah penggunaan berbagai media dan metode pembelajaran yang dapat menarik minat siswa dalam belajar Bahasa Inggris. Media yang digunakan agar siswa merasa belajar dengan menyenangkan adalah berupa gambar dan video berisi situasi atau kosakata Bahasa Inggris agar yang mudah dipelajari siswa. Metode pembelajaran yang digunakan adalah dengan bernyanyi dan permainan (game).

Secara umum program berjalan dengan baik, karena antusiasme anak-anak dan warga sekitar RT 02 RW 03 Desa Rancawuluh yang mendukung kelancarannya program KKN DR. Kemudian program bimbingan bahasa asing (Inggris) dibuat untuk anak anak Sekolah Dasar di sekitar masyarakat. Program tersebut bertujuan untuk membimbing anak-anak mengenal dan mengembangkan diri dengan mengenal bahasa asing khususnya bahasa Inggris. Program bimbingan bahasa dilaksanakan setiap seminggu 3 kali dengan alokasi waktu 1 jam setiap pertemuannya.

Sebanyak 18 anak mengikuti program ini yang didapatkan dari observasi dan pendataan warga desa Rancawuluh. Berbekal semangat dan kemauan yang kuat anak-anak secara antusias datang untuk belajar. Untuk pelaksanaan kegiatan bimbingan bahasa dilaksanakan pagi jam 10.00-11.00 WIB. Peserta belajar tentang inroducing myself, animals, the part of the body, numbers, spelling alphabet, daily activities dan sebagainya. Dimulai dengan tema introducing myself, anak diminta memperkenalkan identitas diri sendiri menggunakan Bahasa Inggris mencakup nama, asal, alamat rumah, serta asal sekolah, hobi, dan lainnya. Peserta dengan berani maju ke depan kelas dan memperkenalkan diri meskipun menggunakan bahasa campuran antara Bahasa Indonesia dan Inggris. Tak jarang, bahasa Jawa juga ikut andil selama proses pembelajaran tersebut karena bahasa tersebut merupakan mother tongue, dimana bahasa Jawa merupakan bahasa yang pertama kali didengar dan dikenal oleh anak-anak melalui pemerolehan bahasa atau language acquisition oleh orangtua sendiri maupun dari lingkungan sekitar (Gregg, 2007: p.101). Kemudian selalu diakhiri dengan adanya evaluasi dan bimbingan bagaimana caranya memperkenalkan diri secara baik dan benar. Selama pembelajaran tim pengabdi selalu memberikan metode mengajar variaitf di tiap pertemuannya supaya peserta tidak merasa bosan dan cepat memahami materi. Peserta dapat 
belajar sambil bernyanyi ketika melafalkan sebuah alfabet dalam Bahasa Inggris meskipun banyak yang masih bingung dengan pelafalan huruf vokal $a, i, e$. Dengan menyanyikan secara berulang-ulang dan mengingat perbedaannya, akhirnya peserta mampu dengan lancar melafalkannya.

Pada pertemuan berikutnya, pelaksanaan bimbingan belajar bahasa di lakukan dengan metode berbeda dari sebelumnya. Metode pembelajaran bahasa Inggris merupakan kunci pembelajaran (Yamin, M 2017: 85). Ada banyak siswa atau anak-anak yang mampu meraih prestasi baik karena diajarkan menggunakan metode yang tepat dan benar. Peserta bermaina game yang disebut "back to the board" selama pembelajaran. Permainan tersebut bertujuan untuk mengasah daya ingat peserta tentang memorizing a words, sejauh mana peserta mengingat tentang kosakata-kosakata Bahasa Inggris. Peserta membentuk dua tim A dan B. Kemudian peserta berbalik membelakangi papan tulis, sementara pengajar yang membawakan kertas berisi kosakata Bahasa Inggris. Satu dari masing-masing tim maju kedepan dan berbalik untuk menebak kosakata dari lembar kertas yang dibawakan pengajar. Sementara itu, masingmasing tim harus kompak dan bekerja sama untuk menebak dengan cepat dan benar supaya bisa mendapatkan poin 1 . Tim yang membantu tidak diperkenankan menebak langsung secara jelas kosakata yang di belakang, namun peserta harus memvisualisasikan dan menyebutkan beberapa deksripsi yang berhubungan dengan kosakata tersebut. Karena menurut sebuah terori dari (McKay, 2000: 225) bahwa pada usia kecil, secara perkembangan kognitif anak-anak belum mampu berpikir abstrak sehingga akan lebih mudah belajar jika melibatkan penggunaan benda-benda yang konkrit daripada hanya katakata. Setiap anak mendapat giliran untuk melatih pendengaran, daya pikir, dan kemampuan berbicara.

\section{HASIL DAN PEMBAHASAN}

\section{a. Partisipasi dan Pelibatan Masyarakat Sasaran.}

Dalam terlaksananya program KKN DR, masyarakat cukup membantu dan mendukung kelancaran kegiatan program bimbingan belajar Bahasa Inggris. Bentuk partisipasti yang yang dilakukan masyarakat antara lain:

- Anak-anak didik semangat mengajak temanteman dekatnya atau teman sekolahnya untuk bergabung dan belajar ke bimbingan bahasa.

- Anak-anak selalu datang dengan antusias menimba ilmu ke bimbingan belajar bahasa Inggris sepulang dari belajar kelompok.

- Orang tua yang mengantar dan membujuk anak-anaknya untuk mengikuti bimbingan belajar yang diselenggarakan. Bahkan orang tua yang meminta untuk terus melanjutkan program bimbingan bahasa sampai anak-anak bisa mengenal lebih jauh tentang Bahasa Inggris.

\section{b. Pencapaian Anak}


Peserta didik mengenal Bahasa Inggris sebagai bahasa universal, dapat digunakan di seluruh dunia. Mengenal pandangan bahwa sangat penting untuk bisa belajar bahasa asing di era sekarang ini. Peserta bisa mengembangkan kemampuan diri lewat bahasa. Pengenalan Bahasa Inggris sejak usia kecil itu penting untuk menumbuhkan kecintaan, minat, dan ikatan emosional dengan bahasa itu sendiri, sehingga saat dewasa nanti dan menerima pelajaran bahasa Inggris secara formal, anak akan merasakan adanya ikatan dan kecintaan terhadap bahasa Inggris (Asmin, 2013: 193). Meskipun begitu, anak tetap tidak akan lupa dengan bahasa identitasnya yaitu Bahasa Indonesia.

- Peserta didik mulai mengetahui cara belajar memorizing 10 words a day dalam setiap pertemuannya. Menurut Elizabeth B. Hurlock (1978: 114) keterampilan berbicara anak harus didukug dengan pembendaharaan kata atau kosakata yang sesuai dengan perkembangan bahasa. peserta dengan semangat menghafalkan setiap kosakata sesuai dengan caranya masing-masing yang unik dan cepat.

- Dapat mengeja dan mengucapkan kosakata Bahasa Ingrris dengan jelas dan sederhana. Dimana peserta bisa membedakan melafalkan huruf vokal $a, i$, dan $e$.

\section{c. Faktor Pendukung dan Penghambat}

Faktor pendukung:

Motivasi tim pengabdi untuk terus melanjutkan dan mengajarkan bimbingan bahasa Inggris dengan memberikan metode yang menyenangkan selama pembelajaran bahasa Inggris.

Adanya antusiasme yang tinggi dari anakanak dan pihak orang tua sendiri untuk banyak belajar membuat penulis semakin bersemangat memberikan banyak ilmu yang penulis punya karena peserta sudah mengganggap bahwa Bahasa Inggris itu bahasa yang unik.

Faktor penghambat:

Dari segi pembagian waktu yang sedikit sulit tim pengabdi kondisikan berkenaan dengan padatnya jadwal anak-anak di sekolahnya masing-masing karena peserta yang mengikuti program belajar kelompok dan madrasah di luar jam sekolah.

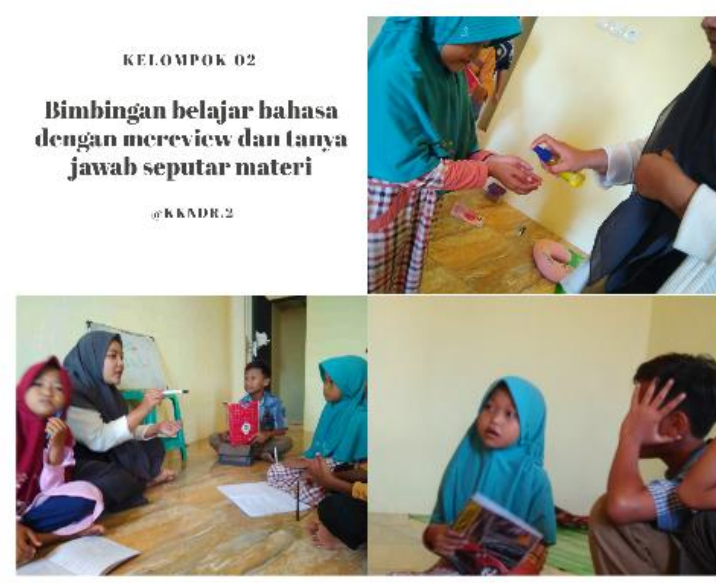

Gambar 1. Pelaksanaan bimbingan bahasa dengan penerapan protokol kesehatan 


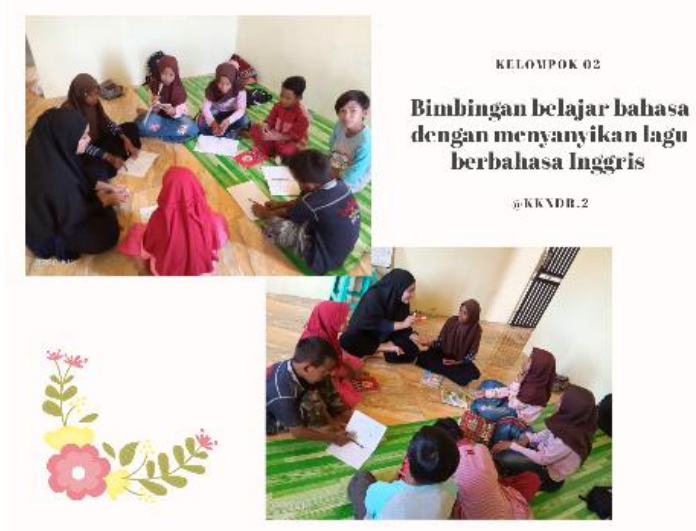

Gambar 2. Menyanyi alfabet dan lagu Bahasa Inggris sebagai pelatihan speaking comprehension

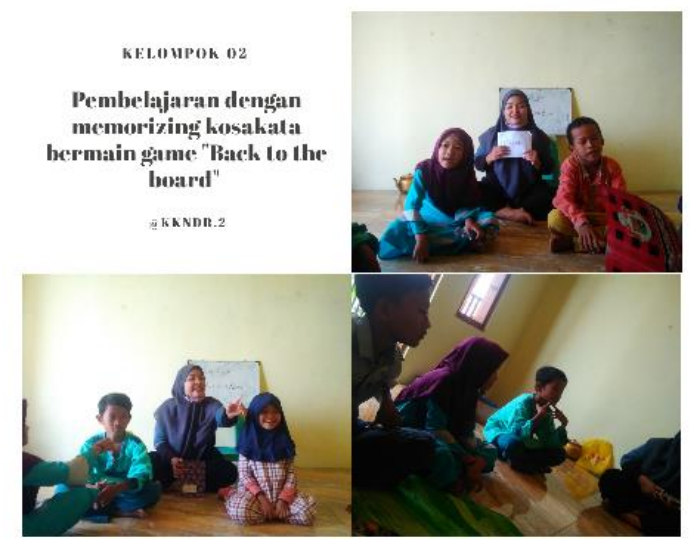

Gambar 3. Bermain game "Back to the Board" selama bimbingan Bahasa Inggris.

Sulitnya mensosialisasikan adanya bimbingan belajar bahasa dikarenakan jadwal yang tidak menentu dari pihak tim pengabdi maupun anak-anak peserta.

\section{KESIMPULAN}

Melalui program KKN-DR yang bertema "Mengenalkan Dan Membangkitkan Minat Bahasa Inggris Pada Anak Di Masa Pandemi Covid 19" selama 31 hari dari tanggal 01 Juli 2020 sampai 31 Juli 2020, tim pengabdi sudah melakukan survei dan observasi terlebih dahulu agar program program yang direncanakan sesuai dengan kebutuhan masyarakat. Program kegiatan KKN-DR 2020 yang dilaksanakan yakni pada bidang pendidikan. Untuk mengenalkan bahasa Inggris kepada anak dan masyarakat Desa Rancawuluh.

Sebanyak 18 anak mengikuti program bimbingan belajar bahasa yang terdiri dari 7 lakilaki dan 11 perempuan. Para siswa menjadi aktif dalam proses pembelajaran. Peserta menikmati proses pembelajaran dan mampu menyelesaikan pertanyaan-pertanyaan ketika bekerja secara individu. Selama kegiatan, masyarakat cukup merespon dan menyambut dengan hangat dengan adanya dukungan dan membantu jalannya semua program rencana kegiatan yang sudah dilaksanakan di Desa Rancawuluh, Kecamatan Bulakamba, Kabupaten Brebes.

\section{SARAN}

Adapun beberapa hal yang perlu diperhatikan dalam pengabdian selanjutya yaitu:

1. Proses pendekatan dan sosialisasi masyarakat harus lebih ditekankan untuk meningkatnya kesadaran akan pentingnya pendidikan untuk anak dari usia kecil.

2. Kegiatan yang akan dilakukan seharusnya harus disesuaikan dengan masalah dan harapan yang terjadi di lokasi pengabdian dengan memerhatikan latar belakang masyarakat juga. 
3. Program bimbingan bahasa dalam masyarakat diharapkan terus berlanjut untuk membimbing anak-anak mengenal dan mengembangkan diri anak-anak melalui bahasa, salah satunya melalui Bahasa Inggris.

\section{DAFTAR PUSTAKA}

Agustina, E., Rohmah, A., \& Kuspiyah, H. (2019). Pendampingan Bimbingan Belajar Bahasa Inggris dan Bakti Sosial di Yayasan Pendidikan dan Sosial Roudlotut Thullab. Jurnal Indonesia Mengabdi, 1(1), 1-5. Retrieved from http://journal.stkipnurulhuda.ac.id/index.php/JI $\underline{\mathrm{Mi} / \text { article/view/415 }}$

Alshenqeeti H. Interviewing as a Data Collection Method: A Critical Review. English Linguist Res [Internet]. 2014;3(1):39-45. Available from: http://www.sciedu.ca/journal/index.php/elr/aticl e/view/4081

Ambaryanti, R. (2013) Hubungan Intensitas Pendampingan Belajar Orang Tua dengan Kualitas Hasil Belajar Siswa di RA Al-Islam Mangunsari 02 Semarang Tahun Pelajaran 2011/2012. Indonesian Journal of Early Childhood Education Studies. 2(2) pp:43-49.

Asmin, A. I (2013). Pengenalan dan Peningkatan Minat Anak Usia Dini untuk Mempelajari Bahasa Inggris. In Prosiding Seminar Nasional (Vol. 2, pp. 191-197)

Christina, Nuning W (2010). English for Kindergarten Student. Talenta Media Utama. Jakarta.

Handayani, T., H.N. Khasanah, R. (2020). Pendampingan Belajar Di Rumah Bagi Siswa Sekolah Dasar Terdampak COVID-19. ABDIPRAJA; Jurnal Pengabdian kepada Masyarakat. 1(1) 107-115.

Gregg, K. R. (2007). Introducing Second Language Acquisition, Muriel Saville-Troike. Studies in Second Language Acquisition, 29(3), 488-489.

Matodang, E. M. (2005) Menumbuhkan Minat Belajar Bahasa Inggris Anak Usia Dini Melalui
Music dan Movement (Gerak dan Lagu). Jurnal Pendidikan Penabur no.5

McKay P. Foregin language teaching in Australian primary schools. In: An early start: Young learners and modern languages in Europe and beyond. 2000. p. 225-48

Ruminda, Dewi Kustanti. (2018) Pelatihan Speed Reading bagi Guru-Guru SD Mata Pelajaran Bahasa Inggris Se-Kecamatan Tarogong Kabupaten Garut, Jurnal AL-Khidmat Vol 1, No 2, pp.55-62.

Ida Setyawan. (2020). Peran Orang Tua Dalam Pendampingan Belajar Daring. Cetta: Jurnal Ilmu Pendidikan, 3(3u). Retrieved from http://jayapanguspress.penerbit.org/index.php/c etta/article/view/955

Yamin, M (2017) Metode Pembelajaran Bahasa Inggris di Tingkat DAS. Jurnal Pesona Dasar, $1(1)$.

Yulianingsih, W., S. Suhanadji, R. Nugroho, M. Mustakim. 2020. Keterlibatan Orang Tua dalam Pendampingan Belajar Anak selama Masa Pandemi COVID-19. Jurnal Obsesi: Jurnal Pendidikan Anak Usia Dini. 5(2). Pp: 11381150. 